Halliday was elected to the British Academy in 2002. He became Montague Burton Professor of International Relations in 2005 before, in his final years, taking up a post as ICREA Research Professor at the Institut Barcelona d'Estudis Internacionals (IBEI). He died of cancer in Barcelona.

Katerina Delacoura London School of Economics

\title{
Frank Tachau
}

1929-2010

THE COMMUNITY OF SCHOLARS OF THE MODERn MiddLE EAST mourns the passing of Frank Tachau, who succumbed to complications caused by multiple myeloma on Friday 23 July 2010 , at the age of 80 .

Frank Tachau was a pioneer in introducing modern social scientific analysis to the study of the Middle East. After training at one of the handful of institutions specializing in Middle East studies in the 1950s, the University of Chicago, where he received his Ph.D. in 1958, he went on to become one of the founders of the field of Middle East political science. He first taught at Rutgers University and then spent the bulk of his career as Professor of Political Science at the University of Illinois, Chicago Circle, where he also served as departmental chair. He continued his connection to the University of Chicago through the years as an Associate Member of its Center for Middle Eastern Studies. In the course of his career, he received numerous honors and visiting positions, including a Fulbright Fellowship; Visiting Noted Scholar at the University of British Columbia; Senior Research Fellow at the Leonard Davis Institute for International Relations, Israel; and visiting professorships in a number of Turkish universities.

Dr. Tachau was a key figure in moving the study of the Middle East from a pure regional specialty to one that used comparative methods in political science, placing the politics of the region in a broader perspective. His well-known book, The Developing Nations: What Path to Modernization? (1972) defined many of the interests that he pursued through his career. Before the term "globalization" even existed, Tachau pursued in the book the 
breakdown of physical barriers of isolation that insulated societies from one another, and he pointed to the emergence of a "world civilization." He was quick to point out, though, that such change would not simply be a process of Westernization and homogenization. On the contrary, the process would be complex and diverse, with important local variations.

His own Middle East research built on important advances in political science in the study of electoral politics, legislatures, parties, and democracies, applying new behavioral and institutional theories to the study of the region. His deepest and most abiding interest was in Turkey, which was in the throes of building democratic institutions punctuated by military coups that threw the process into turmoil. He wrote many scientific papers on Turkey and published a highly influential book on its on-again, off-again democratization, Turkey: The Politics of Authority, Democracy, and Development (1984).

The book sorted out Turkey's post-War history by focusing on the intersection of new democratic institutions, the cultural preoccupation with respect of authority, and the rapid changes that were overwhelming Turkish society, particularly extraordinarily rapid urbanization. He wrote the book in the wake of the new constitution inspired by the country's military leaders as they reinstated democratic institutions. That constitution, of course, became the centerpiece of Turkish politics for the next generation and only recently, in September 2010, was the subject of fierce political struggles as the ruling AK party succeeded in amending it. The book reflected Tachau's great faith that Turkey would eventually succeed in its democratic experiment.

Besides his country work on Turkey (and, later, on Israel, as well), Dr. Tachau was influential in introducing many of the new approaches in political science more comparatively to Middle East Studies. In particular, he argued cogently that Middle East experts need to take institutions seriously, especially the new political institutions taking hold in the post-War era. He edited a series of volumes, including Electoral Politics in the Middle East (1980) and Political Parties of the Middle East and North Africa (1994), which were important efforts in using comparative methods, particularly comparative institutional analysis, in analyzing the region. In Electoral Politics, for example, he compared elected officials in Turkey, Lebanon, and Israel, using structural and behavioral analysis to gauge issues of representativeness and accountability. He was deeply interested in assessing the possibilities for political development and focused on how elites dealt with the rapid social changes in their societies. Political Elites and Political Development in the Middle East (1975), another of these edited volumes, dealt explicitly with 
these problems, focusing on a variety of Middle East elites and how they dealt with rapid change.

If I may add a personal word, I began a lifelong relationship with Frank Tachau at Rutgers, first as a student and, later, as a colleague and friend. Dr. Tachau's class was my first introduction to Middle East studies, and it helped shape the trajectory of my career. Along with many other of his students, I appreciated not only what I learned from him in the classroom but what I learned from a lifetime of association with him. $\%$

Joel S. Migdal University of Washington

\section{Michael J. Zwettler 1940-2010}

Michael J. ZwetTler, Associate PRofessor emeritus at Ohio State University, died of cancer on 25 January 2010. He was a well-loved member of the Department of Near Eastern Languages and Cultures (and its earlier incarnations, beginning with "Department of Romance Languages-Arabic Section") where he taught Arabic language and literature for thirty-five years.

Michael was perhaps best known for his monograph The Oral Tradition of Classical Arabic Poetry: Its Character and Implications (1978), in which he applied the Parry-Lord theory of formulaic composition and rendition to early Arabic poetry. In doing so he covered a much wider range of material than might be expected, with the result that the book remains essential reading for anyone concerned not only with early poetry but with the development of the Arabic language. Scholars have debated at length the question of the language of this poetry: was it the everyday language of the Bedouin, as tradition claimed? Michael argued no, it was a special idiom reserved strictly for formal occasions, utilizing various dialectal features and archaisms (of which the i'rab, the system of case and mood markings, was one), and his arguments have become a standard component of the discussion on the history of Arabic.

The Oral Tradition of Classical Arabic Poetry remains a fixture on Ph.D. reading lists for its important treatment of poetic and linguistic topics, and 280 